\title{
Achieving Online Relationship Marketing via Tourism Blogs: A Social Network Perspective
}

\author{
Carol Hsu \\ Department of Information Management, NTU \\ No.1, Sec. 4, Roosevelt Rd., Taipei City 106, Taiwan \\ carolhsu@ntu.edu.tw \\ Shirley Ou Yang \\ Department of Information Management, NTU \\ No.1, Sec. 4, Roosevelt Rd., Taipei City 106, Taiwan \\ shirleyouyang@ntu.edu.tw
}

\begin{abstract}
Drawing upon the literature on social network analysis, this research examines how part-time marketers use tourism blogs to conduct relationship marketing with their customers. The findings from an interpretive case study indicate that the network pictures of part-time blog marketers can be categorized into three distinct models: the "fan club," the "compliance," and the "creative outlet" models. Our findings also suggest that different network pictures lead to different network management strategies for blogs. Moreover, providing instrumental support and especially material support by blog marketers play significant roles in aggrandizing this transitivity, which helps to attract more visitors to blog sites. We believe that the innovation and the potential connections derived from the individualistic styles of some bloggers and the hedonic emotional support given to tourism blogs should not be overlooked. Our findings also indicate that more incentives and freedom should be provided to tourism business bloggers in order to prosper in their grassroots use of technology.
\end{abstract}

Keywords: Web 2.0 marketing, social networks, business blogging, relationship marketing, tourism industry, qualitative research 


\section{Introduction}

Marketing has undergone significant changes in its content, focus, and boundaries during the past century (Egan, 2008). In particular, the invention of Internet technology has shifted marketing from a transaction-oriented strategy to a relationship-oriented strategy, from a market-based approach to a network-based approach, and from a producer-centric value-creation view to a customer-centric co-creation view (Baker, 2010; Dholakia et al., 2010; Grönroos, 2010). More recently, the deployment of Web 2.0 technologies, such as social networking sites, wikis, and blogs, has made relationship marketing (RM) even more viable.

Among the various Web 2.0 applications, blogs have been gaining increasing popularity over the past few years. According to a recent survey (Nielsen/McKinsey, 2012), the number of blogs grew from 35 million in 2006 to 181 million by the end of 2011. Technorati 2008 also indicates that Asian bloggers are much more active in monetizing their blogs than their European or American counterparts. For instance, $24 \%$ of Asian bloggers are paid to post product reviews on their sites, compared to $5 \%$ of Europeans and $4 \%$ of Americans (White and Winn, 2008). Thus, for Asia at least, the blogosphere is increasingly expanding to support and enhance business and marketing practices.

In this paper, we focus on the deployment of blogs for relationship marketing (RM) in the travel industry. Many tourism organizations have begun launching corporate blogs to improve their marketing channels. The objectives of these business blogs are to not only support product design and help improve the accuracy of targeted marketing campaigns, but also to build one-on-one direct relationships with existing and potential customers through blog networks (Middleton and Clarke, 2009; Schegg et al., 2008; Williams, 2008). From a theoretical perspective, we argue that although integrating IT with customers' demands brings salient influences on establishing and developing customer relationships (Zineldin et al., 1997), most of these studies (Day, 2000; Rigby et al., 2002; Reinartz et al., 2004) hold on to the traditional view of marketing by treating production and consumption as two separate entities. These studies view IT as an instrumental device that facilitates the process of marketing. Less attention has been paid to the transformative impact of blogs, and there is a lack of comprehensive analysis on the transformative impact of collaborative blog networks on building marketing relationships (Dholakia et al., 2010; Zineldin, 2000).

Consequently, the goal of this paper is to fill the gaps within the literature on integrating IT and RM. To echo Zineldin's (2000) call on investigating the indispensable role of technologicalship marketing (RM based on IT), we investigate and explore how part-time marketers use blogs to realize the promises of RM with their customers. Drawing upon the literature on social network analysis, this paper presents a case study on the tourism blog networks of a leading travel service company in Taiwan, with tour guide bloggers as our research subjects. In the context of a travel service company, these bloggers are neither "entirely corporate bloggers" who blog part time or full time for the company nor "social bloggers" who are self-motivated hobbyists. Tour guide bloggers are a unique type of part-time marketer. They normally collect stories or photos as blogging materials during the tours. They also share and discuss customer experiences and feedbacks from each tour. Therefore, blogging provides tour guide bloggers an informal way to interact with their existing customers and potential customers. In other words, the tour guide bloggers adopt blogging not only to establish personal reputations as experts on particular tours, but they also build long-term relationships of trust and friendships with their customers.

Thus, our research objective is threefold: first, to examine how blogs realize the processes of RM; second, to examine tour 
guide bloggers' network pictures of the business blog network; third, to explore how these network pictures lead to the development of different types of relationships in egocentric networks.

The remainder of this paper is organized as follows. The next section discusses the literature associated with business blogging and RM. Section 3 introduces our conceptual framework, followed by a description of our research methodology in Section 4 . We present and analyze the data collected in Section 5 and provide theoretical and practical implications in Section 6. Finally, Section 7 contains some concluding remarks.

\section{Literature Review}

\section{Web 2.0 and Business Blogging in the Travel Industry}

Web 2.0 services, such as social networking sites, wikis, and blogs, have become important in travel planning and buying (Schegg et al., 2008). Personal journal-style blogs, first used for interpersonal goals such as exchanging personal travel experiences among friends, family, and other members of the online community (Nardi et al., 2004; Stehanone and Jane, 2007), have been used for business purposes in the worldwide travel industry.

These major online developments, Web 2.0 and its user-generated content, are reshaping the marketing methods of the travel industry (Wang et al., 2002; Brickart and Schindler, 2001). Travel companies have added more personalized features on their corporate websites than their traditional marketing flyers. Online networks allow these companies to offer new types of services, enhance existing services, and forge new business models and opportunities. Wang et al. (2002) stated, "Online networks have broadened the marketing horizon and are having great impact on marketing, sales, product and service development, supplier network, information quality, and distribution channels."

The travel industry is an information intensive industry since travelers depend on the information they receive to make the best choices for themselves. (Chung and Buhalis, 2008). Corporate blogs take advantage of this appetite for information. Recent studies in tourism have suggested that corporate blogs accelerate information flow, increase productivity, and improve reputation and customer engagement and relationships (Sigala and Christou, 2006; Wang, 2005). By allowing users to interact, exchange, and share their own experiences, corporate blogs turn ordinary users into voluntary travel evangelists spreading the good word of the company.

Blogs, therefore, provide a unique channel for developing and maintaining relationships between organizations and the public (Kelleher and Miller, 2006). As we mentioned earlier, blogging can be used for business and social purposes. Our assessment of the literature indicates that most studies have been concentrating on analyzing social blogging. Examples include studies on the reasons and motivations for blogging (Efimova and Grudin, 2007; Nardi et al., 2004), the structural properties of the social networks of bloggers (Chau and $\mathrm{Xu}$, 2007; Jiang and Wang, 2009; Stefanone and Jang, 2008), and the dynamics and influence of online communities (Agarwal et al., 2008; Dippelreiter et al., 2008; Silva et al., 2008). These works mainly examine social blogging, with a focus on blogging for personal interest and use; none of them addresses the use of blogs in business settings.

Among the existing business blogging studies, some describe the social, relational, and shared benefits that blogging has brought to business (Cass et al., 2005; Jüch and Stobbe, 2005; Jackson et al., 2007; Kelleher and Miller, 2006), while others offer practical guides for helping business owners and practitioners incorporate blog marketing into their strategic business plans (Williams, 
2008; Wright, 2006). Apart from these descriptive studies, few studies have begun to address the complexity of business blogging. In discussing customer engagement via product blogs, Efimova and Grudin (2007) suggested that de facto product blogs created originally as personal blogs existing outside job responsibilities were a more promising communication channel to reach customers and the external community than intentional product blogs. Yardi et al. (2009) suggested that the readers' attention and management support are two influential factors that motivate internal corporate bloggers to contribute to the creation of public goods. At the industry level, Vaast and Davidson (2008), Davidson and Vaast (2009) investigated how tech bloggers as knowledge entrepreneurs build tech discourses collectively.

Despite these valuable insights into the significance of business blogging and the understanding of internal employee bloggers, the relational aspects of business blogging remain unclear. To our knowledge, this study is one of the first studies that investigate the role of tour guide bloggers who serve in between the corporate bloggers and de facto product bloggers as part-time marketers. This particular type of blogger provides a unique context to explore online marketing behavior. Until recently, there was little focus on the interplay between bloggers inside and outside the corporate boundary and the way they manage network relationships. We argue that understanding these relational types of internal and external bloggers is critical to the argument of socially-shaped marketing through blog-enabled RM by part-time marketers. To address this issue, we review the current literature on RM in the following section.

\section{IT and Relationship Marketing}

Marketing theory has been through tremendous changes resulting from the development of economies and technologies. Baker (2010) noted that the essence of marketing is to establish mutually satisfying exchange relationships. However, traditional marketing theory was developed under mass-production-based economies, in which customers rarely met the producers in person. The dominant concept of marketing mix and the 4Ps of marketing-product, price, place, and promotion-have dominated marketing thought, research, and practice since the 1960s in North America and extended itself internationally (Godson, 2009; Grönroos, 1997). We argue that this traditional approach allowed only one-way communication and neglected human variables and relational touches, thus overlooks the importance of "relationships" in the understanding and development of marketing as a business discipline.

In response to a need for an alternative perspective, European marketing research has developed the concept of relationship marketing to cover a very fragmented set of ideas and theoretical frameworks (Möller and Halinen, 2000). Unlike traditional marketing, RM approach considers marketing as a social process and anchor in the exchange characteristics and the exchange context that supports the creation of values for customers over time (Rust and Oliver, 1994). From this perspective, the primary focus is on the interactions and long-term relationships with customers and other stakeholder groups (Dwyer et al., 1987; Gummesson, 1987). In particular, Möller (2010) divided RM literature into two distinct approaches: market-based RM and network-based RM. In both approaches, considerable marketing concepts and research have been developed in the past two decades with different theoretical emphases. The former deals with direct value-chain interaction between the dyadic exchanges of buyers and sellers; the latter takes a more holistic view and characterizes market relationships as interactions within a network-like business and environment. Table 1 shows the differences of the underlying assumptions, managerial challenges, related research topics, and the stream of research they are emerging from, 


\section{Table 1-A Comparison of Market-Based RM and Network-Based RM}

\begin{tabular}{|c|c|c|}
\hline & Market-based RM & Network-based RM \\
\hline $\begin{array}{l}\text { Underlying } \\
\text { assumptions }\end{array}$ & $\begin{array}{l}\text { Deals with direct value-chain } \\
\text { interaction between dyadic } \\
\text { exchanges of buyers and sellers. } \\
\text { The seller is primarily active. }\end{array}$ & $\begin{array}{l}\text { Takes a more holistic view and } \\
\text { characterizes market relationships } \\
\text { as interactions within a network-like } \\
\text { business environment in which any } \\
\text { actor can be active, rather than } \\
\text { isolated dyadic exchanges. }\end{array}$ \\
\hline Managerial challenges & $\begin{array}{l}\text { Acquire and keep large numbers of } \\
\text { customers both individually and } \\
\text { profitably. }\end{array}$ & $\begin{array}{l}\text { Propose a network management } \\
\text { framework to distinguish four levels } \\
\text { of managerial capabilities. }\end{array}$ \\
\hline Related research topics & $\begin{array}{l}\text { Interactive marketing (Grönroos, } \\
\text { 1997), customer relationship } \\
\text { lifecycle (Grönroos, 1983), internal } \\
\text { marketing (Berry, 1981; Grönroos, } \\
\text { 1990), part-time marketer } \\
\text { (Gummesson, 1987, 1991), and } \\
\text { value co-creation (Vargo and Lusch, } \\
\text { 2004) are developed to manage } \\
\text { customer relationships. }\end{array}$ & $\begin{array}{l}\text { Industries as network (Hakansson } \\
\text { and Snehota, 1995), firms within a } \\
\text { network (Cravens, 1996; Hertz, } \\
\text { 1998), managing relationship } \\
\text { portfolios (Turnbull and Zolkiewski, } \\
\text { 1997; York and McLaren, 1996), and } \\
\text { a firm's competence in handling } \\
\text { individual exchange relationships } \\
\text { (Ford, 1990; Möller and Halinen, } \\
\text { 1998; Möller and Wilson, 1995). }\end{array}$ \\
\hline $\begin{array}{l}\text { Original streams of } \\
\text { research }\end{array}$ & $\begin{array}{l}\text { Service marketing (Berry, 1981; } \\
\text { Grönroos, 1990; Gummesson, 1995; } \\
\text { Zineldin et al., 1997), database } \\
\text { marketing, and direct marketing } \\
\text { (interactive marketing) (Jenkinson, } \\
\text { 1995; Kumar, 2008; Malthouse and } \\
\text { Blattberg, 2005; Schultz and } \\
\text { Kitchen, 1997; Shepard, 1995). }\end{array}$ & $\begin{array}{l}\text { Marketing channel relationships } \\
\text { (Geyskens et al., 1998; Heide and } \\
\text { John, 1990, 1992), business } \\
\text { marketing, and network approaches } \\
\text { (Ford, 1990; Ford, 1997; Gemünden } \\
\text { et al., 1997; Möller and Svahn, } \\
\text { 2003). }\end{array}$ \\
\hline
\end{tabular}


respectively (Grönroos, 2010; Möller, 2010).

As mentioned in the introduction earlier, the latest developments in IT and blogs tremendously reshape business and customer relationships and the patterns of market communication (Bughin, 2008; Constantinides and Fountain, 2008; Grönroos, 2010; Möller, 2010). Zineldin (2000) argued that IT should no longer be treated as a separate factor in RM, instead it represents a competitive strategic foundation for creating, developing, and tightening customer relationships, and fulfilling marketing goals. Although the previous marketing literature has recognized the indispensable role IT plays, most of the studies identified above treat technology as a tool (Orlikowski and lacono, 2001). This assumption treats IT as an instrumental device that facilitates the process of marketing; how IT becomes a major influence on RM and fosters the value co-creation process remains unclear. Just as Ford (1997) claimed, "Though technology has a prominent role in organization theory, its absence in marketing theory is conspicuous," the role of IT in enabling RM is still not clear. In this paper, we take an ensemble view of technology.

We argue that the integration of IT and RM allows for different types of synergistic effects that bring market-based RM hand in hand with network-based RM. Powell (1990) stated that in contrast with market and hierarchical governance structures, a network is a new mode of organization. IT should not be simply regarded as an enabler for the increasing interconnectivity in the world (Malone et al., 1987). We contend that IT brings fundamental changes in the social process of marketing and plays an active role in the value-creating process with both suppliers and customers. For example, the development of Web 2.0 technologies enabled suppliers to customize and personalize their products and services by considering the use of online user-participation content, which would speed up the cycle of product design, development, and turnover, and help them design the right products via the right channels with the right prices to reach the right market. In a way, the product/service design is no longer a top-down one-way communication; rather, Web 2.0 technologies enable both the users and service providers to more closely collaborate and co-create innovative services and products. To echo Zineldin's (2000) call on investigating the indispensable role of technologicalship marketing, we move further, investigating the relationships and interplay of the internal and external actors in corporate blog networks.

\section{Conceptual Framework}

In this paper, we focus on a specific type of blogger, the "tour guide blogger," and their relationship types in blog networks. As we explained earlier, tour guide bloggers receive incentives from the travel company to blog and are free to provide travel themes that they are knowledgeable and passionate about. From the marketing perspective, we conceptualize that these new actors in tourism marketing act as "part-time marketers," transcending the simple seller/customer relationship and embodying the network-type relationships in tourism marketing practice. We therefore employ the concept of social networking to look at our data.

\section{Theoretical Base of Social Network}

A social network refers to a structure composed of actors (nodes) and their relationships (links), and it is a method well suited for blog research (Marlow, 2004; Scott, 2007; Zineldin, 2000). The focus of social network analysis is relationships. Unlike variable analysis and topological analysis based on attribute data, social network analysis analyzes relational data and addresses the structure and relationships of objects. As a result, social network analysis can be used to discover the underlying social relationships between tourism blog networks. 
Studies of online communities have done considerable analyses on blog networks (Jiang and Wang, 2009; Paganelli and Guili, 2008; Chau and Xu, 2007; Dippelreiter et al., 2008). However, most of these analyses were whole network analyses and found unevenly distributed structures. For example, Jiang and Wang (2009) analyzed the commentaries of a blog community and found that the comments had a star and fan structure with star and fan relationships. Their results show that "the most noticeable nodes in the network are a few central bloggers who possess a lot of incoming relationships. Each of them is surrounded by a number of ordinary bloggers (fan bloggers) who recognize the central blogger (star bloggers) as their exclusive information source in a star topology" (p.1). Chau and $\mathrm{Xu}$ (2007) also found centers of influence in the social networks of bloggers in online hate groups. They argued that these bloggers might be either opinion leaders or communication hubs.

\begin{tabular}{|l|l|l|}
\hline \multicolumn{2}{|c|}{ Table 2 - A Summary of the Whole Network Analyses of Online Communities } \\
\hline & Research subject of a blog & Findings \\
\hline Jiang and Wang (2009) & $\begin{array}{l}\text { Commentaries and fan structure. } \\
\text { community. }\end{array}$ \\
\hline Chau and Xu (2007) & Online hate groups. & $\begin{array}{l}\text { A structure of opinion leaders or } \\
\text { communication hubs. }\end{array}$ \\
\hline
\end{tabular}

\begin{tabular}{|c|c|c|c|c|}
\hline $\begin{array}{c}\text { Dimensions of } \\
\text { support }\end{array}$ & $\begin{array}{l}\text { Definitions of Wellman and Wortley } \\
\text { (1990) }\end{array}$ & $\begin{array}{c}\text { Fischer's study } \\
\text { (1982) }\end{array}$ & $\begin{array}{c}\text { Cutrona and } \\
\text { Russel (1990) }\end{array}$ & $\begin{array}{l}\text { This } \\
\text { paper }\end{array}$ \\
\hline $\begin{array}{l}\text { Emotional } \\
\text { aid/support }\end{array}$ & $\begin{array}{l}\text { Including minor emotional aid, } \\
\text { advice about family problems, and } \\
\text { major emotional aid. }\end{array}$ & Intimate relations & $\begin{array}{l}\text { Emotional } \\
\text { support }\end{array}$ & $\begin{array}{l}\text { Emotiona } \\
\text { I support }\end{array}$ \\
\hline Small services & $\begin{array}{l}\text { Including minor services, lending } \\
\text { and giving household items, minor } \\
\text { household services, and aid in } \\
\text { dealing with organizations. }\end{array}$ & \multirow[t]{3}{*}{$\begin{array}{l}\text { Relations of } \\
\text { sociability }\end{array}$} & $\begin{array}{l}\text { Tangible } \\
\text { support }\end{array}$ & \multirow[t]{2}{*}{$\begin{array}{l}\text { Instrume } \\
\text { ntal } \\
\text { support }\end{array}$} \\
\hline Large services & $\begin{array}{l}\text { Including major household services } \\
\text { (i.e., regular help with housework) } \\
\text { and major services (i.e., children's } \\
\text { day care and long-term health } \\
\text { care). }\end{array}$ & & $\begin{array}{l}\text { Tangible } \\
\text { support }\end{array}$ & \\
\hline Companionship & $\begin{array}{l}\text { Including discussing ideas, doing } \\
\text { things together, and participating } \\
\text { together in an organization. }\end{array}$ & & $\begin{array}{l}\text { Informational } \\
\text { support and } \\
\text { network support }\end{array}$ & $\begin{array}{l}\text { Informati } \\
\text { onal } \\
\text { support }\end{array}$ \\
\hline $\begin{array}{l}\text { Financial } \\
\text { aid/support }\end{array}$ & $\begin{array}{l}\text { Including small loans and gifts, and } \\
\text { large loans and gifts. }\end{array}$ & $\begin{array}{l}\text { Material } \\
\text { exchanges }\end{array}$ & $\begin{array}{l}\text { Tangible } \\
\text { support }\end{array}$ & $\begin{array}{l}\text { Material } \\
\text { support }\end{array}$ \\
\hline
\end{tabular}


These whole network analyses look at the structural properties of the social networks of bloggers. However, the relationships are not as detailed and significant as the proper analyses that corporate tourism blogs require. In contrast, in our context, we adopted personal network analyses to look at the blog comments, as we considered that personal network analyses revealed one person's set of connections with others in a social network environment, whereas whole network analyses did not. According to Wellman (2007a, 2007b), the individuals at the centers of these networks are called egos; hence, personal networks are also called ego networks. Personal network analyses are used to analyze micro-level buyer-seller relationships in both market-based RM and network-based RM. Therefore, personal networks are better suited than whole networks for the relationships we seek to reveal in this paper.

We drew from previous sociological studies and psychological studies to examine personal networks. For instance, in Fischer's study (1982)of the relation types of friend interactions, he found that friendship ties tended to be primarily relations of sociability (for example, meet each other, hold discussions, share pastimes), intimate relations (for example, discuss personal matters), and material exchanges. Other examples include Wellman and Wortley (1990) who suggested five dimensions of support supplied by different types of relationships: emotional aid/support, small services, large services, companionship, and financial aid/support. In psychological studies, Cutrona and Russel (1985, 1990) proposed similar ideas of social support, including five major dimensions: (1) emotional support, (2) network support, (3) esteem support, (4) tangible support, and (5) informational support. In Table 3, we compared these similar concepts from different areas of study and the related concepts emerging from the relational data in our empirical study.

\section{The Notion of Network Picture}

In order to investigate how tour guide bloggers are sensemaking their relationships with other bloggers in a network, we also draw on the notion of the network picture as an analytical angle. In line with Weick's (1995) notion of sensemaking, "network picture" refers to the different understanding that the actors have of the network. Network pictures are created by the actors' subjective and idiosyncratic sensemaking about the constituting characteristics of the backbone of the managers' understanding of relationships, interactions, and interdependencies, and therefore constitute an important component of their individual decision-making processes (Ford et al., 2002; Henneberg et al., 2006). Network pictures also represent an important aspect of a company's strategy, its strategizing process and tactics within a complex web, and exchange relationships.

In business blogging, full-time marketing managers no longer play a predominant role in effective marketing. Part-time marketers such as bloggers replace the traditional marketing function to support value creation in the marketing process, as they maintain daily direct personal contact with customers and receive their instant responses to and suggestions for products and services. By observing the different network pictures of tour guide bloggers, we are able to understand all possible levels of quasi-managerial activities in corporate blog networks, such as choices within existing relationships and positions and interaction process (Henneberg et al., 2006). The network picture lens could help us deconstruct an organization's network context on two levels: the content of the network and how the pictures represent the content.

\section{Research Approach}

\section{Research Method}

Our case study was conducted on Lion Travel, a major travel company in Taiwan 
that offers both inbound and outbound tours and trips. Lion Travel set up its blog to establish tighter connections with its customers to improve its reputation, increase its customer base, and build communities of fans around "star" tour guides. In 2006, Lion Travel launched its new website, entering the content, community, and commerce (3C) dimension, which made Lion Travel one of the early adopters of Web 2.0 tourism in travel planning and buying. The company stipulated its blog marketing policy and asked its tour guides to be part-time marketers by hosting their own blogs on the company's website. These tour guide blogs were set up for marketing purposes. The company provided training to its affiliated tour guides to blog, building long-term customer relationships online by sharing their travel experiences. As most of the prices of the tour components such as flight tickets, hotels, and entrance fees were fixed, Lion Travel management believed that the tour guide was the only component in trip planning that could add value. Taking advantage of the tour guides' experiences, field knowledge, and charisma, the company hoped to build direct relationships with its customers through the blogs, thereby differentiating its services from its competitors.

In our case study of Lion Travel, we used an interpretive qualitative approach to collect and analyze the data. Specifically, a two-phase study was undertaken. In the first phase, we conducted in-depth interviews with the tour guide bloggers and management team of Lion Travel to determine how they made sense of their blogging. Then in the second phase, we analyzed the comments that were posted on the tour guide blogs on Lion Travel's website. The two phases of data collection were designed to collect relational data both from the service provider's view and from the real-life interactions between the service provider and its customers (in our case, tour guide bloggers and their fan bloggers). In doing so, we expected that the data would expand our current understanding of RM research.

We conducted the first phase of in-depth interviews from October 2009 to February 2010. We conducted 13 semi-structured interviews with tour guide bloggers. We also interviewed seven top and middle managers in order to understand the background and development of the company's $3 \mathrm{C}$ policy and collected internal documents. The interviews covered a set of questions about the corporate blogs, blogging habits, network pictures on blogging, corporate blogging policy, the way they maintained relationships with customers, and the size of their fan base. We used the in-depth interview method to explore deeper customer relationships between tour guide bloggers and their fan bloggers.

Lion Travel has 450 affiliated tour guides. These tour guide bloggers are not formal employees of the company but contractors who lead a certain number of Lion Travel's tours per month. Owing to the fact that only $8 \%$ of these affiliated tour guides have actually complied with the company's blog policy, we chose 13 tour guide interviewees based on a rating list of the company's 2009 corporate blog competition, including both successful and unsuccessful bloggers. We interviewed ten outbound tour guides and three inbound tour guides. As the latter generally shared similar work practices and routines, we did not interview as many inbound tour guides. Of the manager interviewees, some were top management who designed the company's blog marketing policies; others were middle management who executed this policy, including some who were supportive and others who were not as supportive.

In the second phase of this study, we analyzed the comments posted from November 2009 to January 2010 on the top eight corporate blogs hosted by the interviewees. We coded the comments as part of the analysis in order to capture the dynamic relationships in the personal networks of each blog. In order to collect 
relational data, we developed coding categories partly based on the categories used in prior personal network studies, such as name generator (whether or not bloggers used their real names) and relationship types (instrumental support, informational support, material support, and emotional support).

\section{Table 4-Coding Categorie}

\begin{tabular}{|c|c|c|}
\hline Coding construct & Concept & Illustrative quote \\
\hline - Date & $\begin{array}{l}\text { The exact date of the } \\
\text { comment posted on the } \\
\text { blog. }\end{array}$ & 2009/12/2 下午 09:13:33 \\
\hline $\begin{array}{l}\text { - Name of comments } \\
\text { blogger }\end{array}$ & The name of the blogger. & happy post on (date) \\
\hline - Emotional support & $\begin{array}{l}\text { Including minor emotional } \\
\text { aid, advice about family } \\
\text { problems, and major } \\
\text { emotional aid. }\end{array}$ & $\begin{array}{l}\text { "I wasn't in a good mood today ... The whole } \\
\text { company is against me, especially the } \\
\text { witch ..." } \\
\text { "You seem to be pretty frustrated recently! Let } \\
\text { me cheer you up! No matter how your boss } \\
\text { treats you, you are the best. I really miss your } \\
\text { trip." }\end{array}$ \\
\hline $\begin{array}{l}\text { - Instrumental } \\
\text { support }\end{array}$ & $\begin{array}{l}\text { Including large and small } \\
\text { services. }\end{array}$ & $\begin{array}{l}\text { "Thanks for sharing the lovely ice cream picture } \\
\text { with us. It does not look like our ice cream in } \\
\text { I-Lan. Next time when I visit Shui city, will } \\
\text { definitely try it!" } \\
\text { "When are you going to marry? I will definitely } \\
\text { prepare a red envelop for you?" Ans: "Ha! Ha! If } \\
\text { there is any hint, I will inform you ASAP XD" }\end{array}$ \\
\hline - Material support & $\begin{array}{l}\text { Including gifts or goods } \\
\text { from the tour guide } \\
\text { blogger. }\end{array}$ & $\begin{array}{l}\text { "When is your next group to Italy? Could you } \\
\text { please buy some Golden coffee beans for me? } \\
\text { I have run out of coffee beans. I really miss the } \\
\text { smell!" } \\
\text { "I received the trip DVD this noon! Cannot wait } \\
\text { to see it. It is so great that we could be so close } \\
\text { to a glacier. What a great experience. We are } \\
\text { so lucky to have such a professional tour guide } \\
\text { like you. Thanks for the gift you have sent us. } \\
\text { Hope to join your group again." }\end{array}$ \\
\hline $\begin{array}{l}\text { - Informational } \\
\text { support }\end{array}$ & $\begin{array}{l}\text { Including discussing ideas } \\
\text { and sharing travel } \\
\text { information and } \\
\text { experiences. }\end{array}$ & $\begin{array}{l}\text { "Could I bring instant noodles with fish and } \\
\text { shrimp on the airplane? Are the noodles with } \\
\text { meat not allowed to be brought on an airplane } \\
\text { now?" } \\
\text { "When is the best season to have a trip to } \\
\text { German and Czech? How many days do you } \\
\text { suggest us to spend there? How much if you } \\
\text { attend a group tour?" }\end{array}$ \\
\hline
\end{tabular}


We obtained other emerging categories such as customer retention and acquisition information from the blog comments posted by both the tour guide bloggers and their alter bloggers. We conducted a pre-test of a most popular tour guide blog to examine and adjust the categories before the formal coding. The four relationship types were emerging because they appeared the most in the pre-test data set. We rated the relationships with frequent responses in each blog as "strong," those with less frequent responses as "medium," and those with rare responses as "low" based on a comparison within one single blog. For instance, if there was an intensive interaction of comments between the blogger and the customers within one single blog, we considered this as a strong relationship. Network size was defined as the number of different alters who commented on a given blog during a set time. A team of two researchers conducted pre-tests before the formal coding and analyzed the same comments and interview transcripts. Two co-authors of this paper carried out cross-validation. We separately coded the comments and later compared the results with those of our coding. The initial coding results diverged for $25 \%$ of our pre-test sample, causing an in-depth discussion until we reached a consensus of the definition of each category. Table 4 shows the coding categories of this research.

\section{Data Analysis}

\section{Network Pictures of Part-Time Blog Marketers}

To understand the networking relationships between tour guide bloggers and customers, we first used the "network picture" as an analytical lens to look at the tour guide bloggers' subjective and idiosyncratic sensemaking of their relevant business environments (Henneberg et al., 2006). Our analysis identified three types of network pictures that described how tour guide bloggers made sense of these corporate blog networks. These perceptions are by no means exhaustive, covering all corporate bloggers, but they serve as a sample of what we might find in a larger study. We described these three network picture types or models below.

The "fan club" model. Characterized by a network view of blogging as an attention-catching device, these tour guide blog marketers hold most of the top ratings in Lion Travel. These tour guides are normally talented and charismatic. They brand their names and blog proactively and aggressively. They work to become stars on their blogs. They feel that by branding themselves, they garner the company more customers, and in turn, they themselves earn more. Hence, acquiring more fans comes before financial rewards. One outbound tour guide (013) said, "Blogging gives me bargaining power. I have the attention of both my customers and my boss. Frankly, I have used my fans to get bargaining power with my boss."

Although these bloggers view blogs as a means for them to gain financial rewards, they all surprisingly feel that the blogs should be "kept neutral," or not commercial. One blogger (013) said, "I don't talk about anything relating to money in my blog on purpose, because that is not the way to make friends." They note that blogging takes a lot of their time and energy. If blogging no longer catches the attention of the top management, they all say that they will "quit blogging" immediately.

The "compliance" model. Using blogs as an alternative marketing communication channel, this network model represents compliance for these part-time blog marketers. These bloggers are normally not as popular and aggressive as the "fan club" model bloggers, many of them blog 
collaboratively on a team blog, rather than an individual blog. Their posts stick to the company's itineraries and new products. Adding stories, photos, and sometimes film clips of company-selected trips, they construct their blogs akin to expensive advertisements and think the tour guide blogs contribute to the trips' value. One outbound tour guide (007) asserts, "Corporate blogs should relate to corporate interests. It is the company's blog after all. Tour guides shouldn't use the blog as a platform to express their personal opinions."

Blogs lead to the flow of information, which helps share tacit knowledge among tour guides. The blog networks also serve as the company's internal communication channel. Based on the posts of their experiences and the experiences about which the other tour guides have written, the blog marketers design new tours that may better fit the customers' needs to improve the efficiency of marketing communication and increase sales. An inbound tour guide said, "It [the corporate blog] serves as a reference for me. I can learn from other tour guides."

The "creative outlet" model. This model is characterized by a network view of blogs as an opportunity for personal expression rather than as a means to a corporate end. These part-time tour guide marketers personalize their blogs. They adopt technology individualistically and with versatility. Blogger (008) notes, "I do not blog from a tour guide's point of view. I have positioned myself as a traveler, a country $X$ lover. I don't post photos of customers. It is just not my style." She blogs to "document her life" for her own memories and even intentionally conceals her job position on the blog. The drive for expression motivates bloggers like her to keep blogging. Another blogger (002) says, "Blogs are personal. Every blog has its own character. Tourist experiences are subjective. I write in a humorous style ... people pay money to have a good time and we need to leave them with good memories when the trip is over."
These bloggers commonly despise selling things on their blogs and are opposed to commercializing their blogs. These bloggers do not closely follow company itineraries or the blogging rules laid down by company policy. Blogging is "for fun." They struggle for more freedom. If the company stopped requiring blogging, they would not be bothered and would likely continue blogging. "I am a blogger no matter whether the company provides an incentive or not," one blogger said.

Zerfaß (2005) addressed the eight functions of corporate blogs: one is for pure public relations, two deliver internal communication (knowledge transfer and contract negation), and five focus on marketing communication (product blogs, service blogs, customer relationship blogs, crisis blogs, and CEO blogs), which can also serve as an internal communication function. Based on our findings, although the three types of tour guide blogs that we found in this study were used for marketing communications, the "compliance" model was more similar to the product blogs and service blogs, while the "fan club" model and the "creative outlet" model were more likely to be customer relationship blogs.

From the company perspective, the president of Lion Travel also stated that the diversity of tour guide blogs brings a positive impact on the company's marketing and customer relationship management. $\mathrm{He}(020)$ said,

"The tourism products, such as itinerary, are easy to be copied; however, human beings are difficult to be imitated. It requires much work for us to create incentives for increasing the sense of belongings of our affiliated tour guides to Lion Travel. Empowered by Web 2.0 technology, the unique characters of each tour guide blogger helps us launch inimitable products. By using the interactivity of our blogs, the content co-created by the tour guide bloggers and customers, accumulating community, and community, growing to 
commerce. The power of community generated by Web 2.0 is non-negligible. Normally, a group scattered immediately after trips, but a tour guide blog kept people there. "

"The user-contributed content and community enable our marketing to be more and more accurate. A Web 2.0 social media platform, such as blog or Facebook, is simply a reflection of all walks of life and preferences of hundreds of millions of people. It helps us to find out what customers are saying, thinking, and sharing. So we could refine the package of our products to increase the degree of matching."

The different models of tour guide blogs also speed up the traditional process of product design. Traditional product designs required long periods for market surveys, development, and market tests. Nonetheless, with the contribution of the various tour guide blogs, Lion Travel now tests its new product designs online. "We packaged the products and tested to the market based on what we learned from the user-contributed content," General Manager (017) said, "if the market does not accept it, we simple change to another package, because the product design is done by Internet marketing, without substantial expense, the cost is relatively low." This led to the development of a new strategy "taking aim at a moving target" at Lion Travel, and creates competitive edges in e-tourism in Taiwan. For instance, given the personal styles of the tour guide bloggers, Lion Travel could differentiate various customer segments based on their personal needs, e.g., a skiing tour, fans tour, honeymoon, etc., unlike a traditional travel agency that only provides one or two different routes for one destination. For instance, Lion Travel can now provide 10-20 diversified products in one charter to New Zealand by targeting different market segments.

\section{Relationship Types of Personal Blog Networks}

Having identified three distinct blog networks, we analyze the relationship styles (as indicated in Table 3) to further the dynamics of the relationships of these tour guide bloggers and their fellow bloggers, and to determine how their different network views of corporate blogs influence their daily blogging. Table 5 presents our coding of the blog comments, the connections between these tour guides and their alter bloggers, and the content of these alter-ego ties.

Our results indicate that tour guide bloggers who picture blog networks as a "fan club" maintain star-fan relationships with other bloggers and have larger network sizes (80 to 700 people), whereas those who view their blog networks as "compliance" have weaker alter-ego ties and smaller network sizes (8 to 65 people). Those who hold a "creative outlet" network picture have strong ties with their alter bloggers and network sizes as diverse as their personal styles.

Our findings show that tour guide bloggers with the same network pictures establish similar relational types of ties with alter bloggers. First, those who picture the blog network as

a "fan club" perceive their blog as a platform to sustain relationships with customers long after the trips are over. Before a trip, these tour guides would post their yearly group schedule on their blogs in order to gather their fans and customers online. During the trip, they take pictures and videotape parts of their trips for customers. Later, they post pictures of customers on their blogs and invite customers to see and participate in their blog. Some even provide incentives to customers to share their photos taken during the trip. Others offer future trip schedules to solicit repeat customers and their families and friends, creating a snowball effect. 


\section{Table 5 - Network Pictures and Types of Relationships within Blog Networks}

\begin{tabular}{|c|c|c|c|c|}
\hline $\begin{array}{l}\text { Network } \\
\text { picture } \\
\text { types }\end{array}$ & Boundaries & $\begin{array}{l}\text { Relationship } \\
\text { styles/interaction }\end{array}$ & $\begin{array}{l}\text { Time/ } \\
\text { task }\end{array}$ & Actors/activities/resources \\
\hline \multirow[t]{4}{*}{$\begin{array}{l}\text { The "Fan } \\
\text { Club" } \\
\text { model }\end{array}$} & \multirow[t]{4}{*}{$\begin{array}{l}\text { Large } \\
\text { ( } 80 \text { to } 700 \\
\text { people) }\end{array}$} & $\begin{array}{l}\text { Instrumental } \\
\text { support }\end{array}$ & High & $\begin{array}{l}\text { Greetings, praise, appreciation, gossip, } \\
\text { share ideas, companionship, fan clubs } \\
\text { on Plurk and Facebook. }\end{array}$ \\
\hline & & Material support & High & $\begin{array}{l}\text { Incentives such as providing free } \\
\text { photography services, tour DVDs, travel } \\
\text { photo posting, and provide photos as } \\
\text { gifts, online souvenir lottery, after-trip } \\
\text { shopping services, and offline } \\
\text { gatherings. }\end{array}$ \\
\hline & & Emotional support & Medium & $\begin{array}{l}\text { Share feelings of depression or } \\
\text { frustration with work, share family } \\
\text { pictures, discuss personal health } \\
\text { problems. }\end{array}$ \\
\hline & & $\begin{array}{l}\text { Informational } \\
\text { support }\end{array}$ & Medium & $\begin{array}{l}\text { Ask about upcoming trips, prices, and } \\
\text { technical problems. }\end{array}$ \\
\hline \multirow[t]{4}{*}{$\begin{array}{l}\text { The } \\
\text { "Complian } \\
\text { ce" model }\end{array}$} & \multirow[t]{4}{*}{$\begin{array}{l}\text { Small } \\
\text { (8 to } 65 \\
\text { people) }\end{array}$} & $\begin{array}{l}\text { Instrumental } \\
\text { support }\end{array}$ & High & $\begin{array}{l}\text { Greetings, gossip, discussion of tourist } \\
\text { spots, encouragement, share ideas, } \\
\text { companionship, push emails. }\end{array}$ \\
\hline & & Material support & Low & Travel photo posting. \\
\hline & & Emotional support & Low & $\begin{array}{l}\text { Avoid responding to anything related to } \\
\text { personal feelings. }\end{array}$ \\
\hline & & $\begin{array}{l}\text { Informational } \\
\text { support }\end{array}$ & High & $\begin{array}{l}\text { Ask about upcoming trips, souvenirs, } \\
\text { food, and equipment. }\end{array}$ \\
\hline \multirow{4}{*}{$\begin{array}{l}\text { The } \\
\text { "Creative } \\
\text { outlet" } \\
\text { model }\end{array}$} & \multirow[t]{4}{*}{ Random } & $\begin{array}{l}\text { Instrumental } \\
\text { support }\end{array}$ & Random & Praise, appreciation, gossip. \\
\hline & & Material support & Random & $\begin{array}{l}\text { After-trip shopping services, travel photo } \\
\text { posting. }\end{array}$ \\
\hline & & Emotional support & Random & Share hedonic feelings. \\
\hline & & $\begin{array}{l}\text { Informational } \\
\text { support }\end{array}$ & $\begin{array}{l}\text { Medium } \\
\text { to high }\end{array}$ & $\begin{array}{l}\text { Discuss pictures and content posted on } \\
\text { the blog. }\end{array}$ \\
\hline
\end{tabular}


The coding of comments in Table 5 reveal that fan bloggers interact often and provide instrumental and material support to star bloggers in this group. Star bloggers even receive some emotional support from specific fans in the sharing of joy and distress. Some star bloggers also provide informational support for their fans.

Second, those tour guide bloggers who view their blog networks as "compliance" perceive their blogs as a way to increase the mutual understanding of their company and customers. The company can now design and change trips through the user-generated innovative idea posts on the blog at a low cost. Through the intensive interaction among tour guide bloggers, a value co-created process by part-time marketers and customers has thus been developed.

"We thought deeper in product design. With the bloggers' feedback, we could now really design a trip to fulfill customers' specific dreams. For example, this year we have designed a mountain climbing trip with an escort handling the backpacks for customers. This design is based on traveler bloggers' constant complaint of lacking physical strength for hiking. Making trips like this means more to me than the competition for the lowest price and repetitive itineraries, as we helped people gain respect for nature," said tour guide blogger (010).

The tour guide bloggers who have this network picture receive high instrumental and informational support from alter bloggers. On their blogs, they generally discuss issues related to traveling, such as their travel experiences, new travel spots, and travel preparation advice. In contrast, they do not receive as much material and emotional support as those who have a "fan club" picture. One tour guide did report that some alter bloggers left comments on her blog seeking emotional support, "I wasn't in a good mood today," and "The whole company is against me, especially the witch ..." However, she and the others hesitate to respond to these kinds of comments. These bloggers have also adopted multiple communication tools such as email, SMS, and phone calls in addition to their blog to keep in contact with their customers.

Third, those who picture their blog networks as a "creative outlet" establish diverse relationships with their alter bloggers. No distinct pattern of their relationships with customers appears among bloggers who view their blogs the same way. Self-expression seems to be a higher priority than creating and maintaining relationships with customers. For example, in order to conceal her tour guide identity, blogger (008) intentionally deletes her customers' comments that mention her name on her blog. Consequently, with just three alter bloggers having posted comments on her blog over the past three months, seeking mostly informational support she has maintained a very small network size. Bloggers like her rarely receive any instrumental, material, or emotional support.

\section{Discussion and Implication}

The previous findings analyze the network pictures of tour guide bloggers and the different relationship ties among their social dynamics on blog networks. In this section, we discuss the theoretical and practical implications of our findings, as well as their limitations and areas for further research.

\section{Network Pictures and Influential Part-Time Marketers}

This study contributes to the body of knowledge on blogging by identifying three distinct types of network pictures of tour guide bloggers: a "fan club" model, a "compliance" model, and a "creative outlet" model. Our analysis of these part-timer marketers has shown different interaction process and outcome from the prior research on corporate blogs. Yardi et al. (2009) contended that internal corporate bloggers perceived the attention of management and other employees as the major motivating factor that encouraged 
them to maintain a corporate blog. However, our interviews suggest that tour guide bloggers' network pictures are much more diverse with different sets of motivating factors. The differences in the scope of external and internal blogs may account for the gap between our findings and the findings of Yardi et al. Unlike internal employee bloggers, external tour guide bloggers feel less pressure to conform to institutional forces and more autonomy-similar to general personal bloggers.

Beside we also contribute to the literature by discussing the relevance of network pictures and how they strengthen social cohesion in business blog setting. Henneberg et al. (2006) stated that network pictures are the "actor's network theory"; the richness of network pictures is clearly dependent on boundary choices. Actors need to decide where they subjectively choose to "cut off" the network picture. Our data report that different network pictures lead to different network management strategies of the blog marketers. Based on our research findings, we suggest that tour guide bloggers for the "fan club" model and tour guide bloggers for the "creative outlet" model could have the capabilities to host more influential blogs and maintain a comparatively larger network size. The influential blogs we defined here are based on the performance ranking of the award winners in the company's yearly blog competitions. The ranking evaluates the influence of corporate blogs by a combination of daily visitors and daily traffic.

The "fan club" model tour guide bloggers are intentionally part-time marketers. They develop competitive advantages and become assets to the company through the public relationships that they provide. In return, these star bloggers are autonomous and free to negotiate corporate resources and support within and outside the corporate boundary. Burt (1992) suggested that "structural holes" have a strategic advantage in negotiating transactions with suppliers and customers in any social network. Those who take possession of these "holes" or "bridges" acquire a competitive advantage in the exchange of information, social capital, and other resources, since they begin to constitute or have constituted the only route through which resources can flow to other parts of the network. Based on this "structural holes" argument, tour guide bloggers who perceive their blog networks as "fan clubs" have access to holes between the managers and their fan customers and then play important roles as "bridges" when the company crosses new frontiers to bring external social capital into its corporate boundary. For example, based on the strong cohesion between the star bloggers and their fans and the valuable user-participation information collected on their blogs, the marketing managers of the company can customize and personalize their product designs online instantly or provide these star tour guides more resources to host interactive blog communities after their trips. Accordingly, the star tour guides have the competitive advantage of facilitating the company's customer retention and acquisition and gaining the attention of top management.

Although garnering the attention of their management and customers is what drives these most active bloggers, not all bloggers want to be or enjoy being the stars. Interestingly, our findings suggest that personal communication and grassroots self-expression are other crucial drivers behind tour guide blogging activities. Like most general personal bloggers, bloggers who fall within the "creative outlets" style are unintentional part-time marketers. They want to express themselves and are not primarily concerned with sales. Their perceptions of blogs are shared by most ordinary bloggers who report in studies that blogging is a form of personal communication and grassroots self-expression (Nardi et al., 2004). They struggle for more freedom and flexibility. For these individualistic bloggers, blogging is "for fun." Surprisingly, some of them attract a large interest group of bloggers. In contrast, bloggers who see their blogs as forms of 
compliance or institutional tools are normally less influential. They are more likely to use blog networks for internal or marketing communication. Although they act as intentional part-time marketers, most of them maintain a smaller network and complain frequently that the pressure to blog is no more than an "extra burden from work without a raise."

Within RM literature, the results from this study have theoretical implication for the research on market-based RM, specifically, the area of part-time marketers. As Gummesson (1991) pointed out, marketing cannot be implemented by one organizational function of marketing specialists, the full-time marketers only. To realize RM, everyone who is involved in communicating the value support process needs to serve as part-time marketers (Grönroos, 2010). Our work goes beyond the traditional view of part-time marketers in market-based RM and discerns more details of RM realized in the context of the blogosphere. We found that personal initiative bloggers who reveal their distinct personalities or charisma, rather than having clear product-focused purposes on the blog network, normally act as more influential part-time marketers. This result echoes Efimova and Grudin's (2007) argument on de facto product weblog, which is centered on personal interests, often written outside of job responsibilities and strongly tied to its author. That is to say, corporate blogs that have less of propaganda function win more of their customers trust in RM.

\section{Marketers Network Pictures and Network Management Strategies}

Our study also adds value to business blog research by demonstrating how these part-time blog marketers maintain relationships and reach out to new customers and networks. First, our comments data shed new light on the current body of knowledge of RM and social networks by indicating how different network pictures incorporate different types of actors, management strategies and activities, recourses, and relationship types in tour guide blog networks. They are similar in some ways but different in others with the friendship networks.

Wellman and Wortley (1990) point out that different people can provide different kinds of support. For example, "friendship" ties, as described in Fischer's classic study of friendship networks (Fischer, 1982), typically represent offers of companionship and sometimes emotional support but little material support. Alternatively, "close" ties, like those of relatives, typically not only offer emotional support but also instrumental and material support. Based on our analysis of alter-ego relationships, the relationship types of tour guide blog networks are somewhat different from friendship networks. Those blog networks that have the most revisiting fan bloggers provide greater instrumental and material support but less emotional support than ordinary friendship networks. That is, while customers regularly revisit the tour guide blog, our qualitative data analysis indicates the interaction between the tour guide and the customers involves less exchange of personal feelings or the discussion on personal issues such as family or individual health conditions as the interaction in a friendship network. Other kinds of support, including instrumental and emotional support, may help in the forming of a network.

Furthermore, instrumental support also leads to the development of "weak ties" in alter-ego relationships, causing effective social cohesion. Granovatter (1973) explains that in a social network, weak ties refer to loose acquaintances, such as those connections made at a party. Their impact on the diffusion of influence and information are different from the impact of strong ties, such as kin relations and close friends. Granovatter proposes that the strength of weak ties could explain the phenomenon that provides people with access to information and resources beyond those available in their own social circles. In determining the extent of information diffusion and connections among cliques in 
large-scale social structures, weak rather than strong ties create more novel information flows to individuals. The mounting page views of Lion Travel's blogs and websites reveal the strength of weak ties that connect to customers and their social networks (see Figure 1).

Emotional support, in addition to entertaining and amusing information as a way of sharing fun, seem to be significant binders in establishing ties among bloggers. Blogger (002), who characterizes his blogging style as humorous, only posted 33 times in the three months observed, yet he received almost 90 comments. Supporting the previous findings, our study suggests hedonic benefits are major factors that motivate participation within the Internet travel community (Chung and Buhalis, 2008). major drivers for employees who participate in blogging (Jackson et al., 2007). Our data show that the "compliance" model of part-time blog marketers reveals similar types of relational ties with other bloggers. We suggest that these results indicate that tour guide bloggers have similar network pictures as internal corporate bloggers. The "fan club" model bloggers, nevertheless, reveal different types of relationship ties, which agree more with what Gwinner et al. (1998) characterized as customer relational benefits in service industries. In our case, those blog marketers tend to provide aggressive material support such as travel photo posting, souvenir lotteries, or shopping services coined as a "commercial friendship" (Price et al., 1996) in some service settings, which may best

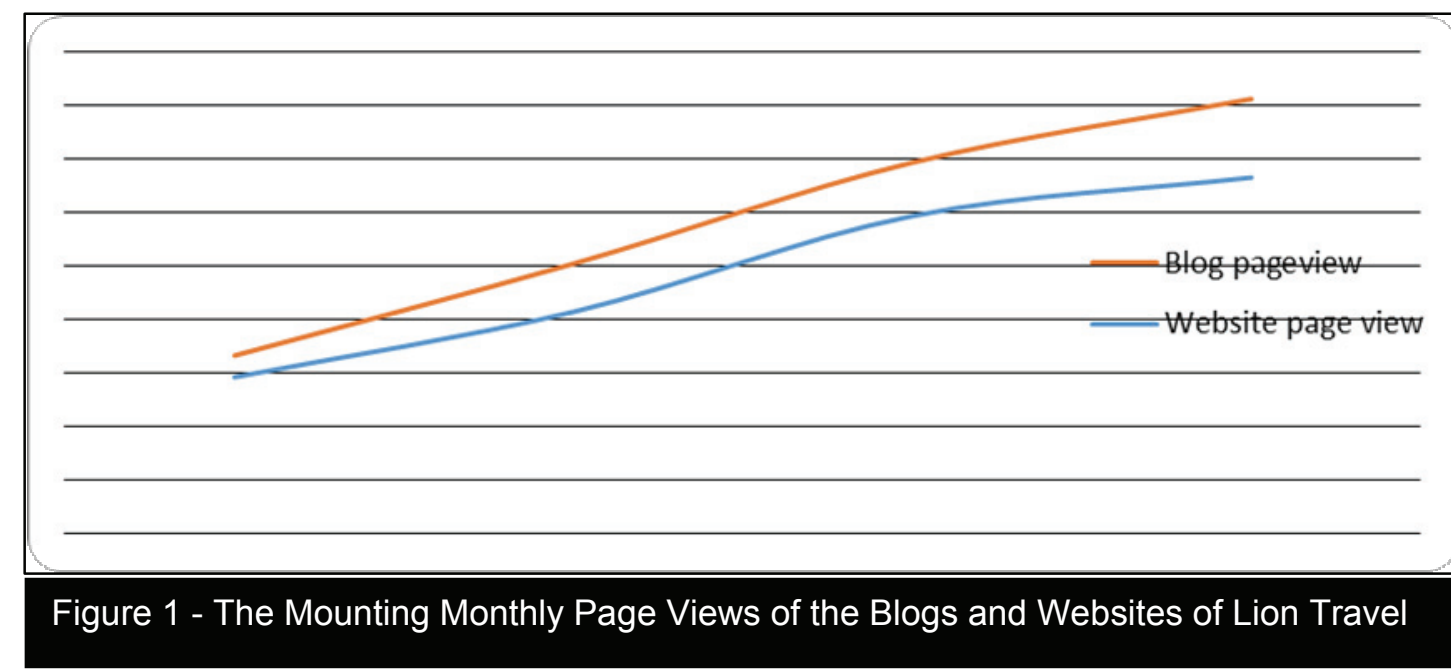

Interestingly, the most active bloggers are not the most influential. Second, our findings also extend the prior network pictures or map concepts a business-to-business exchange level (Henneberg et al. 2006; Ford et al. 2002; and Border et al. (2001). The empirical results of this research show that different network pictures can be applied to various relational scopes to make sense of the blog networks ranging from the traditional supplier-customer level and commercial-friendship level, to the individual actors level.

Anecdotal evidence suggests that social benefits and information benefits are the two characterize the blurry relationship between these star bloggers and their fans. Similarly, for the "creative outlet" bloggers, their network pictures are closer to the viewpoints reported in previous personal blog literature, and they create diverse ties and connect to diverse bloggers whose interests are based on their personal styles. This finding provides evidence of the individual identities of the participants in prior blog communities (Silva et al., 2008) and Giddens' (1991) concept of self-identity in modernity. 


\section{Conclusion}

Blogging technology is, by its nature, bottom-up and grassroots. Even though entrepreneurs and investors have jumped on this bandwagon, our study suggests that there is no single rule to dominate the perceptions and the use of this new technology. Different bloggers (actors) create different network pictures of blog networks, and these differences in perspective lead to different levels of closeness to their alter egos. The alter-ego relationships of corporate bloggers typically have weak ties, and through the "transitive" effect of social networking, these weak ties may bind more alter bloggers and lead to more direct participation. Our study suggests that instrumental support and material support are effective strategies for network management in strengthening the transitivity among bloggers. However, garnering the attention of managers as a motivating factor for some bloggers may bring about stronger ties for them and play an important role in business blogging. This study also suggests that managers should not overlook other factors, such as the individualistic style of bloggers and the hedonic benefits that may motivate bloggers, because these self-motivated bloggers might advance corporate frontiers by sharing specific interests inside and outside the corporate boundary with undeveloped, distant, potential customers. These forerunners of tourist blogging bridge the gap between the internal corporate culture and the external awareness of travel discourse and facilitate the growth of the company as well as the entire travel industry, with the least cost. Empowering business bloggers to blog and keep blogging may begin with instructing them to offer more incentives and giving them more freedom to blog.

In summary, the theoretical and practical implications of this study contribute to our understanding of how tour guide part-time marketers play a role in social network marketing through tourism blogs. This study also shows that the power of a blog blurs the line between the existing market-based RM and network-based RM literature. We also acknowledge the limitations of this research and the areas for further study. This study only focuses on the social dynamics of bloggers and might overlook some other drivers in the value co-creation process of some other stakeholders, for instance the interplay between full-time marketers and part-time blog marketers, the institutional forces in the strategic level of RM in an organization and in a broader sense, the business blog interwork with other social networking media. In the context of a knowledge economy, these are all important areas that need further research. Nonetheless, we believe that the insights from our case study add to the explanations of how and why business blogs came into being and the adaptive circles forming among the actors and their networks.

\section{Acknowledgements}

This work was supported by the Department of Information Management, National Taiwan University and Nation Science Council, Taiwan (NSC 101-2410-H-002-025 and NSC101-2811-H-002-046). An earlier version of this paper has been presented in The Pacific-Asia Conference on Information Systems 2010.

\section{References}

Achrol, R. and Kotler, P. (1999). "Marketing in the Network Economy," The Journal of Marketing, 63, pp.146-163.

Agarwal, N., Liu, H., Tang, L. and Yu, P.S. (2008). "Identifying the Influential Bloggers in a Community," Proceedings of the International Conference on Web Search and Web Data Mining, ACM, pp. 207-218. 
Achieving Online Relationship Marketing via Tourism Blogs/Hsu and Ou Yang

Baker, M. (2000). Marketing Strategy and Management. MacMillan Press: Basingstoke.

Baker, M. (2010). "Marketing- Philosophy or Function?" in Baker, M., Saren, M. (Eds.), Marketing Theory, Sage Publications: Thousand Oaks, CA.

Bikart, B., and Schindler, R. (2001). "Internet Forums as Influential Sources of Consumer Information," Journal of Internet Marketing, 15(3), pp. 31-40.

Berry, L. (1981). "The Employee as Customer," Journal of Retail Banking, 3, pp.33-40.

Borders, A.L., Johnston, W.J. and Rigdon, E.E. (2001). "Beyond the Dyad: Electronic Commerce and Network Perspectives in Industrial Marketing Management," Industrial Marketing Management, 30, pp. 199-205.

Bughin, J. (2008). "The Rise of Enterprise 2.0," Journal of Direct, Data and Digital Marketing Practice, 9, pp. 251-259.

Burt, R. (1992). Structural Holes-the Social Structure of Competition. Harvard University: Cambridge, MA.

Butow, E. and Bollwitt, R. (2010). Blogging to Drive Business: Create and Maintain Valuable Customer Connections. Que Publishing: Indianapolis, Indiana.

Cass, J., Munroe, K. and Turcotte, S. (2005). Corporate blogging: Is It Worth the Hype, Backbone Media.

Chau, M. and Xu, J. (2007). "Mining Communities and their Relationships in Blogs: A Study of Online Hate Groups," International Journal of Human-Computer Studies, 65, pp. 57-70.

Chung, J.Y. and Buhalis, D. (2008). "Information Needs in Online Social Networks," Information Technology \&Tourism, 10, pp. 267-281.
Constantinides, E. and Fountain, S.J. (2008). "Web 2.0: Conceptual Foundations and Marketing Issues," Journal of Direct, Data and Digital Marketing Practice, 9, pp.231-244.

Cravens, D., Piercy, N. and Shipp, S. (1996). "New Organization Forms for Competing in Highly Dynamic Environments: the Network Paradigm," British Journal of Management, 7, pp. 203-219.

Davidson, E. and Vaast, E. (2009). "Tech Talk: An Investigation of Blogging in Technology Innovation Discourse," Professional Communication, IEEE Transactions on Professional Communication, 52, pp. 40-60.

Day, G. (2000). "Capabilities for Forging Customer Relationships," Report No. 00-118. Marketing Science Institute: Cambridge, MA.

Dholakia, N., Zwick, D. and Denegri-Knott, J. (2010). "Technology, Consumers, and Marketing Theory," in Maclran P., S., M., Stern, B. and Tadajewski, M. (Eds.), The Sage Handbook of Marketing Theory, Sage Publications: Thousand Oaks, CA, pp. 494-512.

Dippelreiter, B., Grun, C., Pottler, M., Seidel, I., Berger, H., Dittenbach, M. and Pesenhofer, A. (2008). "Online Tourism Communities on the path to Web 2.0: An evaluation," Information Technology \& Tourism, 10, PP. 329-353.

Dwyer, F., Schurr, P. and Oh, S. (1987). "Developing Buyer- seller Relationships," The Journal of Marketing, 51, pp. 11-27.

Efimova, L. and Grudin, J. (2007). "Crossing Boundaries: A Case Study of Employee Blogging," Proceedings of the 40th Hawaii International Conference on System Sciences (HICSS). IEEE, Hawaii, pp. 86-86.

Egan, J. (2008). "A Century of Marketing," The Marketing Review, 8, pp. 3-23. 
Everett, M. and Borgatti, S.P. (2005), "Ego Network Betweenness," Social Networks, 27, pp. 31-38.

Fischer, C. (1982). "What Do We Mean by "Friend'? An Inductive Study," Social Networks, 3, pp. 287-306.

Ford, D. (1990). Understanding Business Markets: Interaction. Relationships and Networks. Academic Press: London.

Ford, D. (1997). Understanding Business Markets. Academic Press: London.

Ford, D., Gadde, L., Hakansson, H. and Snehota, I. (2002). "Managing Networks," Proceedings of the Asia IMP Conference, Perth.

Gemünden, H.G., Ritter, T. and Walter, A. (1997). Relationships and Networks in International Markets. Pergamon: Kidlington, UK.

Geyskens, I., Steenkamp, J. and Kumar, N. (1998). "Generalizations about Trust in Marketing Channel Relationships Using Meta-analysis1," International Journal of Research in Marketing, 15, pp. 223-248.

Giddens, A. (1991). Modernity and self-identity: Self and society in the late modern age. Stanford University Press: Stanford, CA.

Godson, M. (2009). Relationship Marketing. Oxford University Press: New York.

Grönroos, C. (1983). Strategic Management and Marketing in the Service Sector. Marketing Science Institute: Cambridge, MA.

Grönroos, C. (1990). "Relationship Approach to Marketing in Service Contexts: The Marketing and Organizational Behavior Interface," Journal of Business Research, 20, pp. 3-11.

Grönroos, C. (1997). "Keynote Paper from Marketing Mix to Relationship Marketing- towards a Paradigm Shift in Marketing," Management Decision, 35, pp. 322-339.

Grönroos, C. (2010). "Relationship Marketing as Promise Management," in Maciran P., S., M., Stern, B. and Tadajewski, M. (Eds.), The Sage Handbook of Marketing Theory, Sage Publications: Thousand Oaks, CA.

Granovetter, M. (1973). "The Strength of Weak Ties," American Journal of Sociology, 78, pp. 1360-1380.

Gummesson, E. (1987). "The New Marketing--Developing Long- term Interactive Relationships," Long Range Planning, 20, pp. 10-20.

Gummesson, E. (1991). "Marketing-orientation Revisited: the Crucial Role of the Part-time Marketer," European Journal of Marketing, 25, pp. 60-75.

Gummesson, E. (1995). Relationship Marketing: From 4Ps to 30Rs. Malmo: Liber-Hermods.

Gwinner, K., Gremler, D. and Bitner, M. (1998). "Relational Benefits in Services Industries: the Customeri ${ }_{1}^{\prime} s$ perspective," Journal of the Academy of Marketing Science, 26, p. 101.

Hakansson, H., Snehota, I. (1995). Developing Relationships in Business Networks. Routledge: London.

Heide, J. and John, G. (1990). "Alliances in Industrial Purchasing: the Determinants of Joint Action in Buyer-supplier Relationships," Journal of Marketing Research, 27, pp. 24-36.

Heide, J. and John, G. (1992). "Do Norms Matter in Marketing Relationships?" The Journal of Marketing, 56, pp. 32-44.

Henneberg, S., Mouzas, S. and Naude, P. (2006). "Network Pictures: Concepts 
Achieving Online Relationship Marketing via Tourism Blogs/Hsu and Ou Yang

and Representations," European Journal of Marketing, 40, pp. 408-429.

Hertz, S. (1998). "Domino Effects in International Networks," Journal of Business-to- Business Marketing, 5, pp. 3-31.

Jüch, C. and Stobbe, E. (2005). "Blogs: The new Magic Formula for Corporate Communications?" Deutsche Bank Research, 53, pp. 1-7.

Jackson, A., Yates, J.A. and Orlikowski, W. (2007). "Corporate Blogging: Building Community through Persistent Digital Talk," Proceedings of the 40th Hawaii International Conference on System Sciences (HICSS), IEEE, Hawaii.

Jenkinson, A. (1995). Valuing Your Customers: From Quality Information to Quality Relationships Through Database Marketing. McGraw Hill Book Co.: London.

Jeong, S. (2008). "Collective Production of Public Goods in Online Travel Communities," Information Technology \& Tourism, 10, pp. 355-373.

Jiang, T. and Wang, X. (2009). "How do Bloggers Comment: An Empirical Analysis of the Commenting Network of a Blogging Community," Proceedings of the International Conference on Information Systems (ICIS), Phoenix.

Lankshear, C. and Knobel, M. (2008). Digital Literacies. Peter Lang Publishing New York, NY.

Kelleher, T. and Miller, B. (2006). "Organizational Blogs and the Human Voice: Relational Strategies and Relational Outcomes," Journal of Computer Mediated Communication, 11, pp. 395-414.

Kumar, V. (2008). Managing Customers for Profit: Strategies to Increase Profits and Build Loyalty. Wharton School Publishing: Philadelphia, PA

Möller, K., 2010. "Relationships and Networks," in Baker, M.J. and Saren, M. (Eds.), Marketing Theory: A Student Text, SAGE Publication: Thousand Oaks, CA.

Möller, K. and Halinen, A. (1998). "Consumer Versus Interorganisational Relationship Marketing: a Metatheoretical Analysis," in Sheth, J., Menon, A. (Eds.), New Frontiers in Relationship Marketing Theory and Practice, Emory University: Atlanta, GA.

Möller, K., Halinen, A. (2000). "Relationship Marketing Theory: its Roots and Direction," Journal of Marketing Management, 161, pp. 29-54.

Möller, K., Svahn, S. (2003). "Managing Strategic Nets--A Capability Approach," Marketing Theory, 3, pp. 209-234.

Möller, K. and Wilson, D.T. (1995). Business Marketing: An Interaction and Network Perspective. Kluwer Academic Publishing Boston, MA.

Malone, T.W., Yates, J. and Benjamin, R.I. (1987). "Electronic Markets and Electronic Hierarchies," Communications of the ACM, 30, pp. 484-497.

Malthouse, E.C. and Blattberg, R.C. (2005). "Can We Predict Customer lifetime value? "Journal of Interactive Marketing, 19, pp. 2-16.Marlow, C. (2004). "Audience, Structure and Authority in the Weblog Community, "Proceedings of the International Communication Association Conference, Montréal.

Mattsson, L., 2003. "Reorganization of Distribution in Globalization of Markets: the Dynamic Context of Supply Chain Management," Supply Chain Management: An International Journal, 8, pp. 416-426. 
Middleton, V. and Clarke, J. (2009). Marketing in Travel and Tourism. Butterworth- Heinemann: Burlington, MA.

Nardi, B., Schiano, D., Gumbrecht and Swartz, L. (2004). "Why We Blog," Communications of the ACM, 47, pp. 41-46.

O'Reilly, T. (2007). "What is Web 2.0," Communication Strategies, 1, p. 17.

Orlikowski, W. and lacono, C. (2001). "Desperately Seeking the IT in IT Research: A Call to Theorizing the IT Artifact," Information Systems Research, 12, pp. 121-134.

Pshsnrlli, F. and Guili, D. (2008). "Context-Aware Information Services to Support Tourist Communities," Information Technology \& Tourism, 10, pp.313-327.

Powell, W. (1990). "Neither Market nor Hierarchy: Network Forms of Organization," Research in Organization Behavior, 12, pp. 295-336.

Price, L.L., Arnould, E.J. and Hausman, A. (1996). "Commercial Friendships: Service Provider-client Relationship Dynamics, "Proceedings of the Frontiers in Services Conference, Vanderbilt University, Nashville, TN.

Reinartz, Werner, Manfred Krafft, and Wayne D. Hoyer (2004). "The Customer Relationship Management Process: Its Measurement and Impact on Performance," Journal of Marketing Research, 41 pp. 293-305.

Rigby, Darrell K., Frederick Reichheld, and Phil Schefter (2002). "Avoid the Four Perils of CRM," Harvard Business Review, 80, pp.101-109.

Rust, R. and Oliver, R. (1994). "Service Quality: Insights and Managerial Implications from the Frontier," in Rust, R., Oliver, R. (Eds.), Service
Quality: New Directions in Theory and Practice. Sage publications: Thousand Oaks, CA.

Schegg, R., Liebrich, A., Scaglione, M. and Ahmad, S. (2008). "An Exploratory Field Study of Web 2.0 in Tourism," in O'Connor, P., Höpken, W., Gretzel, U. (Eds.), Information and Communication Technologies in Tourism 2008, Springer Wien: New York, pp. 152-163.

Schultz, D., Kitchen, P. (1997)." Integrated Marketing Communications in US Advertising Agencies: An Exploratory Study," Journal of Advertising Research, 37, pp. 7-18.

Scott, J. (2007). Social Network Analysis: A Handbook. Sage Publications: Thousand Oaks, CA.

Shepard, D. (1995). The New Direct Marketing: How to Implement a Profit-Driven Database Marketing Strategy. Irwin Professional: New York, NY.

Sigala, M. and Christou, E. (2006). "Investigating the Impact of E-Customer Relationship Management on Hotels' Website Service Quality," Proceedings of Europe Conference of Information System (ECIS) 2006.

Silva, L., Goel, L. and Mousavidin, E. (2008). "Exploring the dynamics of blog communities: the case of MetaFilter," Information Systems Journal, 19, pp. $55-81$.

Stefanone, M., Jang, C. (2008). "Writing for Friends and Family: The Interpersonal Nature of Blogs," Journal of Computer- Mediated Communication, 13, pp. 123-140.

Turnbull, P.W., Zolkiewski, J.M. (1997). "Profitability in Customer Portfolio Planning," in Ford, D. (Ed.), Understanding Business Markets, Dryden Press: London. 
Achieving Online Relationship Marketing via Tourism Blogs/Hsu and Ou Yang

Vaast, E. and Davidson, E. (2008). "New Actors and New Media in Technology Discourse: An Investigation of Tech Blogging," Proceedings of the International Conference on Information Systems (ICIS) 2008, Paris.

Vargo, S. and Lusch, R. (2004). "Evolving to a New Dominant Logic for Marketing," Journal of Marketing, 68, pp. 1-17.

Wang, Y., Yu, Q. and Fesenmaier, D. R. (2002). "Defining the Virtual Tourist Community: Implications for Tourism Marketing," Tourism Management, 23, pp. 407-417.

Wang, G. A. (2005). "Business Blogging e-Hub: An Innovative Approach to E-business," Global Commerce and Cyber Trade, pp. 23-26.

Weick, K.E. (1995). Sensemaking in Organizations. Sage Publications: Thousand Oaks, CA

Wellman, B. (2007a). "Challenges in Collecting Personal Network Data," Field Methods, 19, pp. 111-115.

Wellman, B. (2007b). "Editorial: The Network is Personal: Introduction to a Special Issue of Social Networks," Social Networks, 29, pp. 349-356.

Wellman, B. and Wortely, S. (1990). "Different Strokes from Sifferent Folks: Community Ties and Social Support," American Journal of Sociology, 96, pp. 558-588.

White, D. and Winn, P. (2008). Technorati's State of the Blogosphere 2008 report.
Williams, D. (2008). Biz Blog Marketing--the Secrets of Business Blog Marketing. Doug Williams and Associates: Vancouver, WA.

Wright, J. (2006). Blog Marketing. McGraw-Hill Companies: New York.

Yardi, S., Golder, S. and Brzozowski, M. (2009). "Blogging at Work and the Corporate Attention Economy," Proceedings of $\mathrm{CHI}$ 2009, ACM, Boston.

Yoo, K. and Gretzel, U. (2008). "What Motivates Consumers to Write Online Travel Reviews?" Information Technology \& Tourism, 10, pp. 283-295.

York, D. and McLaren, S. (1996). "The Development and Optimisation of a Client Portfolio," Proceedings of the 12th IMP Conference, Karlsruhe.

Zerfaß, A. (2005). "Corporate Blogs: Einsatzmöglichkeiten und Herausforderungen," BIG BlogInitiativeGerman.

Zineldin, M. (2000). "Beyond Relationship Marketing: Technologicalship Marketing," Marketing Intelligence \& Planning, 18, pp. 9-23.

Zineldin, M., Johannisson, B., and Dandridge, T.C. (1997). "Strategic Relationship Management: A Multidimensional Perspective: towards a New Co-opetive Framework on Managing," Marketing and Organizing, Coronet Books Inc: Philadelphia, PA. 


\section{About Authors}

Carol Hsu is a Professor in the Department of Information Management at National Taiwan University. She holds a Ph.D. in information systems from the London School of Economics and Political Science. Her current research interests focus on the organizational and institutional approach to information security management and technology implementation. Her work has been published in the MIS Quarterly, Information Systems Research, European Journal of Information Systems, and Communications of the ACM. Carol also serves as Associate Editor of the Information Systems Journal and Information \& Management.
Shirley Ou Yang is a Postdoctoral Research Fellow at National Taiwan University, and Adjunct Assistant Professor in the Department of Mass Communication at Tamkang University, Taiwan. She received her $\mathrm{Ph} . \mathrm{D}$. degree in Information Management from Nation Taiwan University in 2012 and MIMS in I-School at UC Berkeley. Her research interests are mainly devoted to social media and social network, risk knowledge management and communication, qualitative research and other intersections between technology, organization and society. Her work has been published by Journal of Electronic Commerce Research. 